\title{
Ownership Structure and Corporate Governance as The Affecting Factors of Liquidity Policy in Consumption Goods Industry Sector Companies in Indonesian Stock Exchange
}

\author{
Erric Wijaya \\ STIE Indonesia Banking School \\ erric.wijaya@ibs.ac.id \\ Dita Noviany \\ STIE Indonesia Banking School \\ ditanoviany@yahoo.com
}

\begin{abstract}
This study discusses the influence of ownership structure and corporate governance as affecting factors to liquidity policy in consumer goods industry sector of companies listed in Indonesia Stock Exchange. The dependent variable in this research is liquidity policy which can be proxied with cash holdings, while the independent variables in this research are: ownership structure that can be proxy by insider ownership and foreign ownership, and corporate governance which can be proxy by with variable board size and board composition, firm size and growth sales as a variable control. This research uses multiple linear regression method with panel data approach. The sample used 21 companies in manufacturing industry which classified into consumer goods sector during the period 2012-2015. The result of the research shows that the variable of ownership structure is only variable insider ownership which has influence to cash holding. While from the corporate governance variable, it is only board size that affect cash holding. The value of adjusted $\mathrm{R}$ squared in this study amounted to $92.6 \%$.
\end{abstract}

Keywords: cash holding, insider ownership, foreign ownership, board size, board composition

\begin{abstract}
Abstrak
Penelitian ini membahas mengenai pengaruh struktur kepemilikan dan corporate governance sebagai factor yang mempengaruhi kebijakan likuiditas pada perusahaan sektor industri barang konsumsi di Bursa Efek Indonesia. Variabel dependen pada penelitian ini adalah kebijakan likuiditas yang diproxy dengan cash holdings, sedangkan variabel independen dalam penelitian ini adalah: struktur kepemilikan yang diproxy dengan kepemilikan perusahaan dan kepemilikan asing, corporate governance yang di proxy dengan variabel board size dan board composition, ukuran perusahaan dan pertumbuhan penjualan sebagai variabel kontrol. Penelitian ini menggunakan metode regresi linear berganda dengan pendekatan data panel. Sampel yang digunakan adalah perusahaan manufaktur sektor industri barang konsumsi yang berjumlah 21 perusahaan selama periode 2012-2015. Hasil penelitian menunjukkan bahwa variabel struktur kepemilikan hanya variabel insider ownership yang memiliki pengaruh terhadap cash holding. Sedangkan variabel corporate governance, hanya board size yang berpengaruh terhadap cash holding. Adapun nilai adjusted $R$ squared dalam penelitian ini sebesar $92.6 \%$.
\end{abstract}

Kata Kunci: Kinerja keuangan bank, risiko kredit, risiko pasar, efisiensi operasional, permodalan, likuiditas

\section{Introduction}

A company is a place to manage economic activities in order to make money (Ross, Westerfield, and Jaffe, 2010). The economic activities a company are doing is related to the input and a funds for the company or buys a number of stocks of a company and there is a manager who will manage them to make profit. (Bokpin, Isshaq, \& Aboagye-Otchere, 2011). Related to the investor and manager, it is seen that in a company there is a separation between funding and management (Bokpin, Isshaq \& Aboagye-Otchere, 2011). This then will further imply that there is a separation between ownership and control which implicates the ownership structure. The ownership 
structure is proxied by insider ownership which is the proportion of the number of ordinary shares held by managers in that particular company (Ira, 2012) and foreign ownership, which is the percentage of share ownership by foreign investors (Adelia, 2012).

Managers and investors want their interests to be achieved to the fullest, so there is a need to keep these differences of interest within the minimum range (Jensen \& Meckling, 1976). According to Surya \& Yustiavandana (2006) in maintaining the differences of interest in so that it will stay within the minimum, there should be a system of corporate governance being applied. In other words, corporate governance is expected to monitor the relationship between the principal and the agent. Corporate governance is proxied with the board size, that is, the number or the right amount of board of commissioners to perform its duties (Clara, 2015) and board composition is the size of independent commissioners to reduce the abuse of authority that may not be performed by independent commissioners (KNKG, 2006).

Corporate governance oversight is the managers of companies that are expected to manage the company well so that it can indirectly reduce the agency cost (Hansen \& Crutchley, 1989). Reduced agency costs will cause excess cash (Papaioannou, Strock, \& Travlos, 1992). This cash surplus can be utilized to safeguard the liquidity of the company by paying its obligations (debt) in a timely manner (Kasmir, 2010). Companies that can pay all their obligations are called liquid companies, while companies that can not pay their obligations are called illiquid (Harmanto, 1987). According to Ginglinger \& Saddour (2007), they stated that shareholders with strong power will let the company hold more cash (Cash holdings). Cash holdings are measured by the natural logarithm of cash and cash equivalents at the end of the year or as of December 31 that are owned by the company (Fitri, 2012).

This condition will raise the questions of whether the ownership structure will historically manage the money invested by the investor well and whether the improper implementation of corporate governance will make money management in the company also worsen. Thus, research on the influence of ownership structure and corporate governance on corporate liquidity policy becomes crucial to be done in Indonesia.

To answer the question of how the influence of ownership structure and corporate governance on company liquidity policy Indonesia, this research will use samples from consumer goods industry manufacturing companies in Indonesia Stock Exchange from the period of 2012 until 2015. Such companies have been chosen because this type of companies has the biggest contribution by sectoral. There is a good investment opportunity in the future especially for long term investment, this is because the consumer good industry sector tend to survive in the midst of declining economic conditions because of its trait as a basic need (Kusumajati, 2009).

Research conducted by Papaioannou, Strock \& Travlos (1992), Nadeem (2015) concluded that insider own- ership variables negatively affect cash holdings, which is different from Bokpin, Isshaaq \& Aboagye-Otchere's (2011) findings since they concluded that it did not negatively affect cash holdings. The research conducted by Mangena and Tauringana (2007) states that the variable of foreign ownership has a positive effect on cash holdings, which is, again, different from Bokpin, Isshaaq \& Aboagye-Otchere's findings in 2011, Hamidullah's findings in 2012, and Luo \& Hachiya's findings in 2005, which all said that it negatively affects cash holdings. Research conducted by Dawn (2014) concluded that board size variables negatively affect cash holdings, which is different from Bokpin, Isshaaq \& Aboagye-Otchere's (2011) research and Kusnadi's (2003) research which both said it has a positive effect on cash holdings.

Research conducted by Modolo (2010) said that board composition variable has a positive effect to cash holdings, which is different to a research that was conducted by Bokpin, Isshaaq \& Aboagye-Otchere (2011) that said it has a negative effect to cash holdings.

Based on the background and the phenomenon, the problem that will be studied are:

1. Does insider ownership negatively affect the liquidity policy of consumer goods companies in Indonesia Stock Exchange (IDX) in the period of 20122015?

2. Does foreign ownership negatively affect the liquidity policy of consumer goods companies in Indonesia Stock Exchange (IDX) in the period of 2012-2015?

3. Does the board size have a positive effect on the liquidity policy of consumer goods companies in Indonesia Stock Exchange (IDX) in the period of 2012-2015?

4. Does board composition negatively affect the liquidity policy of consumer goods companies in Indonesia Stock Exchange (IDX) in the period of 2012-2015?

\section{Theoretical Framework and Hypothesis Develop- ment \\ 2.1 Agency Theory}

Agency theory is the separation of ownership (principal / investor) and control (agent / manager) (Fala, 2007). According to Wiyarsi (2012) there are two problems in agency theory: (1) when the goals of investors and managers are different and shareholders can not supervise what managers can and can not do because of difficult of accessing information in that direction or the high cost of access, (2) principal and agent have different attitudes in looking at risks that will make this principal and agent each take different action. In agency theory, the relationship between principal and agent could be minimized by aligning the interests of both parties. The presence of managerial share ownership is used to reduce the potential agency costs (Nurmasari, 2015).

\subsection{Signal Theory}

Signal Theory (theory of signaling) is based on the idea that well-informed managers will attempt to convey information to investors about how management views 
company's prospects (Brigham and Houston, 2001). Managers usually have better information compared to outside parties (investors), if investors are less informed there will be an information asymmetry between managers and investors. to avoid information asymmetry, companies must provide information as a signal to the investor.

The company must provide information on its picture of cash management to attract investors and potential investors to invest, because if company has a good cash management and high level of cash, it will give a signal that the company can maintain its liquidity, share good incentives to investors, and has a good corporate governance through optimal cash management (Luo \& Hachiya, 2005).

\subsection{Liquidity}

Liquidity is the level of a company's ability to pay its short-term liabilities (Subramanyam, 2010). A company that is capable of fulfilling its financial obligations on time means that the company is in a liquid state, while a company that is not capable of fulfilling its payment at the time it is billed or when the obligation is at maturity, it means that the company is in an illiquid state. Companies that have high levels of liquidity tend to have a funding system that is dominated by equity or self-financing in the sense of funding with relatively little debt (Windy, 2012).

\subsection{Cash Holdings}

Cash is the most liquid asset and is the measure of company's responsibility on paying all of its obligations on time (Dawn, 2014). According to Gill and Shah (2012) cash holdings are cash held by the company or cash that are available for investment in physical assets and can be distributed to investors. Cash holdings are important because to maintain the liquidity of a company, they need to reserve its cash at least in accordance with the minimum amount set for liquidity to be maintained (Saunders \& Cornett, 2003). In a company, the management knows that cash has a very important meaning in supporting every activity of the company. Therefore, there are two theories that illustrate liquidity with cash holdings:

\subsubsection{The Trade-off Theory}

In theory, trade-offs are related to cash holdings which state that the optimal level of liquidity is a trade-off between the costs and benefits of holding cash. The most obvious benefit of withholding cash is to avoid financial difficulties, cash does not interfere with investment policy when financial constraints are met, also, withholding cash can lower external fundraising costs or liquidate assets in urgent situations (Ferreira and Vilela, 2004).

\subsubsection{Pecking Order Theory}

Pecking Order Theory assumes that cash holdings have a role as a buffer between retained earnings and investment needs in maintaining the level of corporate liquidity. When cash is available in excess amount, then the excess cash will be paid to the shareholders in a form of dividend (Myers \& Majluf, 1984). Management can determine cheaper sources of financing. The sources of corporate financing come from three sources: (1) internal financing, (2) issuing debt, and (3) new equity (Prasentianto, 2014). With the availability of sufficient cash, the company does not have to sacrifice its investment opportunities to maintain liquidity (Prasentianto, 2014).

\subsection{Ownership Structure}

The ownership structure is a form of commitment from shareholders to delegate control at a certain level to managers. The term of ownership structure is used to indicate that the important variables in liquidity policy are not only determined by debt and equity but also determined by the percentage of ownership of shares by insiders or foreign parties. The ownership structure will have different motivations in monitoring the company as well as its management and board of directors. The ownership structure is believed to have the ability to influence the running of the company which can affect the company's liquidity due to the control of the company to manage the cash held (Wahyudi and Pawestri, 2006).

\subsubsection{Insider Ownership}

The ownership structure is proxied by insider ownership which represents the proportion of common stock ownership (board of commissioners and directors) within the company as measured by the percentage of ownership held by management (Ira, 2012). The higher the managerial ownership in a company the higher the motivation of managers to improve their performance. Managerial ownership is expected to help achieving corporate objectives by increasing the wealth and welfare of shareholders (Masdupi, 2005).

\subsubsection{Foreign Ownership}

Foreign ownership is the percentage of share ownership by foreign investors (Adelia, 2012). According UU No. 25 of 2007 on article 1 point 6 , foreign ownership is an individual foreign citizen, foreign business entity, and/ or foreign government that are investing in the territory of Republic of Indonesia within the ESDM Regulation No. 27/2013 Article 27 Paragraph (3) that states foreign investment in Indonesia by $49 \%$.

\subsection{Corporate Governance}

General guidelines of Good Corporate Governance in Indonesia are issued by the National Committee on Governance Policy (KNKG) in 2006 which contains statements that said corporate governance functions as a social control in order to maintain the integrity of the parties concerned in the company. The Indonesian Institute of Corporate Governance (IICG) in 2012 defines corporate governance as a series of mechanisms that direct and control a company so that the company's operations run in line with the expectations of the stakeholders. According to Shiefler and Vishny (1997) conclude that corporate governance is one way to ensure finances within the company are well managed. 


\subsubsection{Board Size}

The size of the board of commissioners (board size) is the exact number of members of the board of commissioners within the company to perform its duties (Clara, 2015). The composition of the board of commissioners should be set in such a way as to enable the decision-making to be effected effectively, promptly, and may act independently. The management of the company in Indonesia adopts a two-board system in which the company has two separate bodies namely the supervisory board (board of commissioners) and the management board (board of directors).

\subsubsection{Board Composition}

The board composition is part of the board of commissioners responsible for the company and dismiss the top managers (KNKG, 2006). The existence of an independent commissioner is concerned with decision making on cash (Bokpin, Isshaq, and Aboagye-Otchere (2011). Existence of independent commissioners is to reduce the possible misuse of authority that may be performed by an independent commissioner. According to the National Committee on Governance Policy (KNKG), the increasing number of independent board of commissioners means that the supervision of cash will be more stringent and objective so that frauds could be minimized.

\subsection{Interrelationship Between Variables and Hypothesis}

\subsubsection{Insider Ownership Influence on Liquidity Policy}

Insider ownership is the ownership of shares owned by the managers of the company. According to the agency theory, there is a separation between ownership (princi$\mathrm{pal}$ / investor) and control (agent / manager). In this case, the shareholder hands over his / her authority to the manager to manage his or her wealth. Managers have a certain percentage of the stock gains that are gained. So that makes a difference, if there is a high cash amount it will provide an opportunity for the manager to take advantage of the benefits for himself. Meanwhile, a low amount of cash can harm the company because liquidity can not be maintained. However, in this case the shareholder (investor) who also doubles as a manager within the company also has a wealth of shares and wants a certain percentage of the profits gained. Nadeem (2015) and Papaioannou, Strock and Travlos (1992) showed a negative managerial ownership of cash holdings. This happens because managers have the opportunity to push their needs in the use of corporate cash that will cause asymmetric information and hold more cash so that liquidity can not be maintained. Thus, the first hypothesis in this study are:

$\mathrm{H}_{01}=$ Insider Ownership does not negatively affect the liquidity policy of manufacturing companies in the consumer goods industry group listed on Indonesia Stock Exchange (IDX) in period of 2012-2015.

$\mathrm{H}_{\mathrm{a} 1}=$ Insider Ownership negatively affects the liquidity policy of manufacturing companies in the consumer goods industry group listed on Indonesia Stock Exchange (IDX) in period of 2012-2015.
2.7.2 Foreign Ownership Influence on Liquidity Policy.

Foreign ownership is the percentage of share ownership by foreign investors (Adelia, 2012). According to signal theory, good corporate cash management as a positive signal conveyed by managers to outside parties (investors) to tell whether the company has a good cash management and high level of cash, to foreign investors this reflects that the company has good prospects in the future because it is profitable for foreign investors who invest and benefit the company so that they'll get capital. Mangena and Tauringana (2007) argued that foreign ownership has a positive effect on cash holdings while Bokpin, Isshaq, and Aboagye-Otchere (2011), Hamidullah (2012), and Luo and Hachiya (2005) stated that foreign ownership negatively affects cash holdings. This is inversely proportional to the signal theory which indicates that the positive signals that managers give to foreign investors provide feedback for companies where foreign investors feel confident to invest funds in the company. Thus, utilized by block holders, a group of foreign shareholders who have the power to pursue high equity shares in the company in order to gain maximum profit. Thus, giving a negative signal for the company because it is detrimental in reducing the company's cash money for high dividend payments and sacrificing liquidity. The second hypothesis in this study are:

$\mathrm{H}_{02}=$ Foreign ownership does not negatively affect the liquidity policy of manufacturing companies in the consumer goods industry group listed on Indonesia Stock Exchange (IDX) in period of $2012-2015$.

$\mathrm{H}_{\mathrm{a} 2}=$ Foreign ownership negatively affects the liquidity policy of manufacturing companies in the consumer goods industry group listed on Indonesia Stock Exchange (IDX) in period of $2012-2015$.

\subsubsection{Board Size Influence on Liquidity Policy}

Board size is the right amount of board of commissioners within the company to perform its duties. The number of boards of commissioners should be established in such a way that decision-making can be proceeded effectively, appropriately, and independently. According to Jensen (1996), the larger number of commissioners the less likely will it function effectively. This is in line with Bokpin, Isshaq, and Aboagye-Otchere (2011) and Kusnadi (2003) who argued that board size has a positive effect on cash holdings. This is because the greater the board of commissioners in a company the easier it is for them to facilitate the work because the work can be divided into many groups and it is easier to do specialization because it has a large number of boards and it varies so that the impact on companies can be more effective on maintaining the level of liquidity. Thus, the third hypothesis in this study are:

\footnotetext{
$\mathrm{H}_{03}=$ Board size does not positively affect the liquidity policy of manufacturing companies in the consumer goods industry group listed on Indonesia Stock Exchange (IDX) in period of $2012-2015$.
}

$\mathrm{H}_{\mathrm{a} 3}=$ Board size positively affects the liquidity policy 
of manufacturing companies in the consumer goods industry group listed on Indonesia Stock Exchange (IDX) in period of $2012-2015$.

\subsubsection{Board Composition Influence on Liquidity Pol- icy}

Board composition is the number of independent board of commissioners within the company (Ira, 2012). According to the general guidelines of Good Corporate Governance Indonesia, the National Committee on Governance Policy (KNKG) of 2006 which states that the number of independent commissioners must be able to ensure that the oversight mechanism will operate effectively and they will have the responsibility to encourage the implementation of good corporate governance principles through the empowerment of the board of commissioners so that they can perform the task of supervision to the directors effectively as well. Modolo (2010) argued that board composition has a positive effect on cash holdings. Thus, the fourth hypothesis in this study are:

$\mathrm{H}_{04}=$ Board composition does not positively affect the liquidity policy of manufacturing companies in the consumer goods industry group listed on Indonesia Stock Exchange (IDX) in the period of 2012 - 2015.

$\mathrm{H}_{\mathrm{a4}}=$ Board composition positively affects the liquidity policy of manufacturing companies in the consumer goods industry group listed on Indonesia Stock Exchange (IDX) in the period of $2012-2015$.

\subsection{Research Framework}

Based on the development of the hypothesis, the research framework is as follows in picture 1 .

\section{Research Methods \\ 3.1 Population and Samples}

Population is a generalization region consisting of objects or subjects that have a certain quantity and characteristics set by the researchers to be studied and then drawn conclusions of (Sugiyono, 2010). The population of this study is 38 manufacturing companies in the consumer goods industry group listed on the Indonesia Stock Exchange in the period of $2012-2015$. Selection of research sample is based on the method of nonprobability sampling or to be exact the purposive sampling method with aim to get representative sample according to the criterion specified. The criteria used to select the sample in this study are as follows in table 1 .

\subsection{Operational Variables}

This study uses the dependent variable of Liquidity Policy as measured by cash holdings. Cash holdings formulated by Bokpin, Isshaq, and Aboagye-Otchere (2011) is as follows:

\section{LnCH = Ln In cash \& Cash Equivalents}

The four independent variables are Insider Ownership (IO), Foreign Ownership (FO), Board Size (BS), and Board Composition (BC):

Insider Ownership (IO) or managerial ownership formulated by Bokpin, Isshaq, and Aboagye-Otchere (2011) is as follows:

\section{$I O=\%$ share by board and manager}

Foreign Ownership (FO) is formulated by Bokpin, Isshaq, and Aboagye-Otchere is as follows:

\section{$F O=\%$ of shares by foreign investors}

Board Size (BS) is formulated by Bokpin, Isshaq, and Aboagye-Otchere (2011) is as follows:

\section{BS $=$ Number of board of commissioners}

Board Composition (BC) is fomulated by Bokpin, Isshaq, and Aboagye-Otchere (2011) is as follows:

\section{$\mathrm{BC}=$ Proportion of independent commissioners}

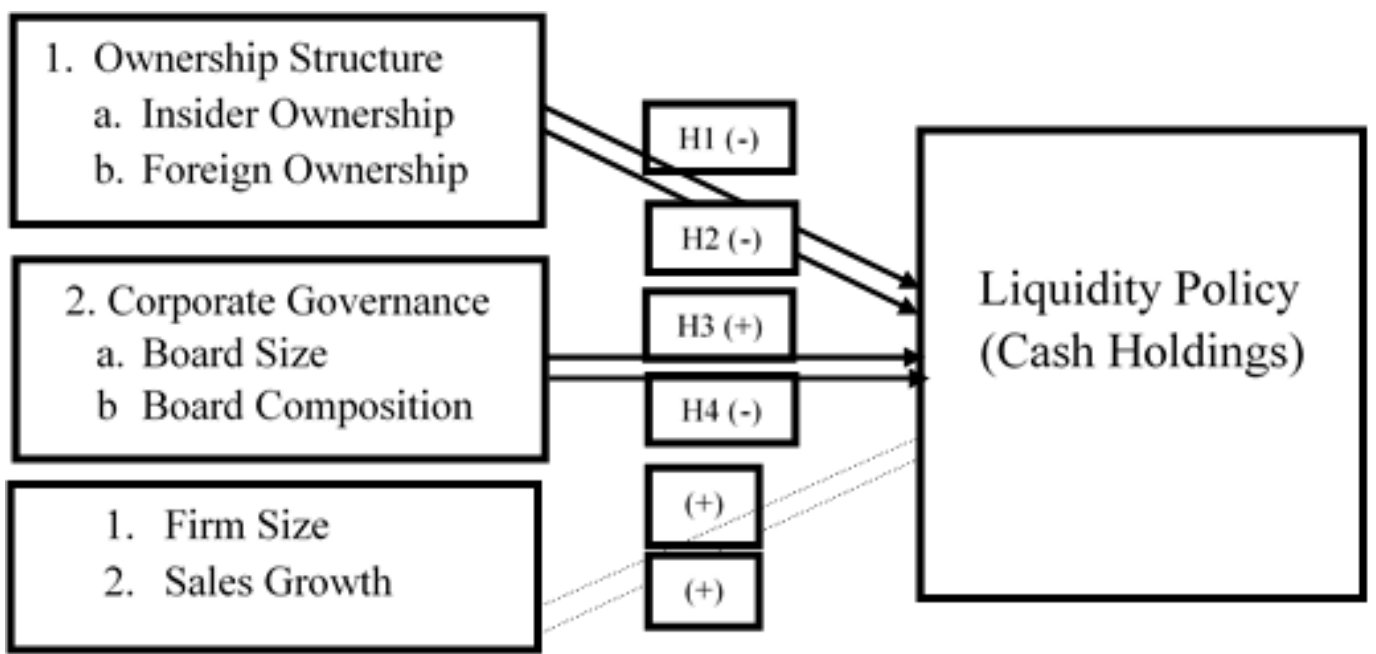

Picture 1. Research Framework

source: author processed data 
Table 1. Manufacturing Companies Sample

\begin{tabular}{llc}
\hline No. & \multicolumn{1}{c}{ Explanation } & Total \\
\hline 1. & $\begin{array}{l}\text { Manufacturing companies in consumer goods sector that are listed on IDX in the period of } \\
2012-2015\end{array}$ & 38 \\
2. Companies that issued annual reports consecutively during the years of $2012-2015$. & 35 & $(14)$ \\
3. Companies that have incomplete financial data related to research variables & 21 \\
4. Company data that can be analyzed
\end{tabular}

Source : www.idx.co.id, Author processed data

The two control variables are firm size (LnSize) and i

Sales Growth (Growth):

Firm Size is proxied into the natural logarithm of total assets in the company by Hamidullah (2012) and is as follows:

\section{LnSIZE $=$ Ln Total Assets}

Sales Growth is calculated based on this year's sales growth from previous year by Papaioannou, Strock and Travlos (1992) and is as follows:

\section{GROWTH $=\underline{\text { Net Sales }(t)-\operatorname{Net} \text { Sales }(t-1)}$}

\section{Net Sales (t-1)}

\subsection{Data Analysis Method \\ 3.3.1 Descriptive Analysis}

Descriptive analysis gives a description or a picture of a data seen from the mean, standard deviation, variance, maximum value and minimum value (Ghozali, 2009).

\subsubsection{Regression Model}

Linear regression illustrates how much influence the dependent variable affects independent variables. The regression equation is as follows:

\begin{tabular}{|c|c|}
\hline $\operatorname{LnCH}_{\mathrm{i}, \mathrm{t}}=\boldsymbol{\alpha}+\boldsymbol{\beta}$ & $\begin{array}{l}{ }_{2} \mathrm{FO}_{\mathrm{i}, \mathrm{t}}+\boldsymbol{\beta 3 B S}_{\mathrm{i}, \mathrm{t}}+\boldsymbol{\beta}_{4} \mathrm{BC}_{\mathrm{i}, \mathrm{t}}+\beta 5 \mathrm{Ln}- \\
{ }_{6} \mathrm{GRTH}_{\mathrm{i}, \mathrm{t}}+\mathrm{e}_{\mathrm{i}, \mathrm{t}}\end{array}$ \\
\hline $\mathrm{LnCH}_{\mathrm{i}, \mathrm{t}}$ & $=$ LnCash holdings company i \\
\hline $\begin{array}{l}\beta_{1}, \beta_{2}, \beta_{3}, \beta_{4}, \beta_{5}, \beta_{6} \\
\mathrm{IO}_{\mathrm{i}, \mathrm{t}}\end{array}$ & $\begin{array}{l}=\text { Regression coefficient } \\
=\text { Insider ownership of com- } \\
\text { pany } i \text { in period }\end{array}$ \\
\hline $\mathrm{FO}_{\mathrm{i}, \mathrm{t}}$ & $\begin{array}{l}=\text { Foreign ownership of com } \\
\text { pany } i \text { in period } t\end{array}$ \\
\hline $\mathrm{BS}_{\mathrm{i}, \mathrm{t}}$ & $\begin{array}{l}=\text { Board size of company } \mathrm{i} \text { in } \\
\text { period } \mathrm{t}\end{array}$ \\
\hline $\mathrm{BC}_{\mathrm{i}, \mathrm{t}}$ & $\begin{array}{l}=\text { Board composition of com } \\
\text { pany } \mathrm{i} \text { in period } \mathrm{tt}\end{array}$ \\
\hline $\operatorname{LnSIZE}_{\mathrm{i}, \mathrm{t}}$ & $\begin{array}{l}=\text { LnFirm size of company } \mathrm{i} \\
\text { in period } \mathrm{t}\end{array}$ \\
\hline GROWTH $_{\mathrm{i}, \mathrm{t}}$ & $\begin{array}{l}=\text { Sales growth of company } i \\
\text { in period } t\end{array}$ \\
\hline$\alpha$ & $=$ Constants \\
\hline & $=$ Error \\
\hline
\end{tabular}

$=$ Company

$=$ Period $/$ Time

\subsubsection{Classical Assumption Test}

The classical assumption test is used to find out if all of the regression models that are being used can create the best estimation and to know the problems in the model. There are four types of tests that are being performed namely: normality test, heteroscedasticity test, multicollinearity test, and autocorrelation test (Ghozali, 2007).

\section{Results and Discussion}

\subsection{Descriptive Statistics Analysis}

1. Cash Holdings $(\mathrm{CH})$ as the dependent variable in this study shows that the mean value of manufacturing companies in consumer good industry during the period of $2012-2015$ is $R p$ 16.301.386.925.650,-

2. Insider Ownership (IO) as the independent variable in this study shows that the mean value manufacturing companies in consumer good industry during the period of $2012-2015$ is $23.9 \%$

3. Foreign Ownership (FO) as the independent variable in this study shows that the mean value of manufacturing companies in consumer good industry during the period of $2012-2015$ is $49.6 \%$

4. Board Size (BS) as the independent variable in this study shows that the mean value of manufacturing companies in consumer good industry during the period of $2012-2015$ is 2 units.

5. Board Composition (BC) as the independent variable in this study shows that the mean value of manufacturing companies in consumer good industry during the period of $2012-2015$ is 1 unit.

6. Firm Size (SIZE) as the control variable in this study shows that the mean value of manufacturing companies in consumer good industry during the period of 2012 - 2015 is $R p$ 8.392.825.348.077,-

7. Sales Growth (Growth) as the control variable in this study shows that the mean value of manufacturing companies in consumer good industry during the period of $2012-2015$ is $14.8 \%$

\subsection{Multiple Regression Test \\ 4.2.1 Panel Data Test \\ 4.2.1.1 Chow Test}

This test is used to compare common effect model 
Table 2. Descriptive Statistics Analysis Result

\begin{tabular}{lccccccc}
\hline & $\begin{array}{l}\text { CH } \\
(\mathbf{R p})\end{array}$ & IO & FO & BS & BC & $\begin{array}{c}\text { SIZE } \\
(\mathbf{R p})\end{array}$ & GROWTH \\
\hline Mean & 16.301 .386 .925 .650 & 0.239 & 0.496 & 1.600 & 1.035 & 8.392 .825 .348 .077 & 0.148 \\
Maximum & 573.360 .267 .681 .001 & 0.773 & 0.941 & 5.000 & 3.000 & 91.831 .526 .000 .000 & 1.273 \\
Minimum & 2.264 .143 .520 & 0.001 & 0.000 & 1.000 & 0.500 & 94.955 .970 .131 & -0.999 \\
\hline
\end{tabular}

Source: Author Processed Data

Table 3. Chow Test Result

\begin{tabular}{lccc}
\hline \multicolumn{1}{c}{ Effect Test } & Statistic & d.f. & Probability \\
\hline Cross Section F & 20.058416 & $(18,40)$ & 0.0000 \\
Cross Section Chi-Square & 149.838672 & 18 & 0.0000 \\
\hline
\end{tabular}

Source: Author Processed Data Using EVIews 9

with the fixed effect model (Ghozali, 2013). The criteria for testing is if the probability value of Cross Section Chi Square is $\geq 0.05$, therefore this research uses the Common Effect Model. However, if the probability value of Cross Section Chi Square is $<0.05$ then this research will be using the Fixed Effect Model and will continue to do Hausman Test.

Based on Table 3, the value of Cross Section ChiSquare probability is 0.0000 , so the regression model that this research is using will be the Fixed Effect Model and will continue on using the Hausman Test.

\subsubsection{Hausman Test}

This test is conducted to select the best model of research, so in this test it will cause to result in the use of the best model by using fixed effect or random effect. The criteria of the testing is if the probability value of Cross Section Chi Square is $\geq 0.05$ then this research will be using the Random Effect Model. However, if the probability value of Cross Section Chi Square is $<0.05$ then this research will be using the Fixed Effect Model.

Based on Table 4 the probability value of Cross-Section Random is 0.0412 . Thus, the regression model that will be used in this research is the Fixed Effect model.

\subsubsection{Classical Assumption Test 4.2.2.1 Normality Test}

This test is conducted to test whether the residual data obtained in this research has a normal distribution or not (Ghozali, 2007). The criteria of this testing is using the Jarque-Bera Test. The data had been distributed normally if the probability is $\geq 0.05$.

Based on Figure 2, the probability value is 0.053837 which is above the $\alpha=0.05$ conditions, with this result it can be concluded that the data has been distributed normally.

\subsubsection{Multicollinearity Test}

The multicollinearity test is used to test whether there is a linear correlation between the independent variables (Gujarati, 2007). The way to look at problems in multicollinearity is to use correlation matrix. The criteria for this test is when the value of coefficient between variables is $>0.8$ it means that this model contains elements of multicollinearity (Gujarati, 2007).

Based on table 5, the correlation between variables is quite low. From the results of multicollinearity test above, all variables show that the coefficient value are below 0.8 , so there is no multicollinearity in the models of this research.

\subsubsection{Autocorrelation Test}

This test is conducted to test whether there is a correlation between observed members by time (such as periodic data) or space (such as cross-sectoral data) (Gujarati, 2007).

Based on Table 6, this autocorrelation test uses a significance level of 0.05 and uses a decision rule under $\mathrm{d}_{u}$ $<\mathrm{d}<4-\mathrm{d}_{\mathrm{u}}$. The number of independent variables $(\mathrm{k}=$ $6)$ and the amount of data $(n=65)$ yields a d of 1.871 , whereas in the DW tables seen in Gujarati's (2007) book with $\mathrm{k}=6$ and $\mathrm{n}=65$ produced a dL (DW lower limit) of 1.404 and $\mathrm{dU}$ (DW upper limit) of 1.805, 4-dL $=2.596$ and $4-\mathrm{dU}=2,195$. Therefore, the value of DW 1.871 means that there is no autocorrelation.

\subsubsection{Heteroscedasticity Test}

This test is conducted to test whether the linear regres-

Table 4. Hausman Test Result

\section{Test Summary Chi-Square.Statistic Chi-Square. d.f. Probability}

\begin{tabular}{llll}
\hline Cross-Section Random & 13.115860 & 6 & 0.0412 \\
\hline
\end{tabular}

Source: Author Processed Data Using EVIews 9 


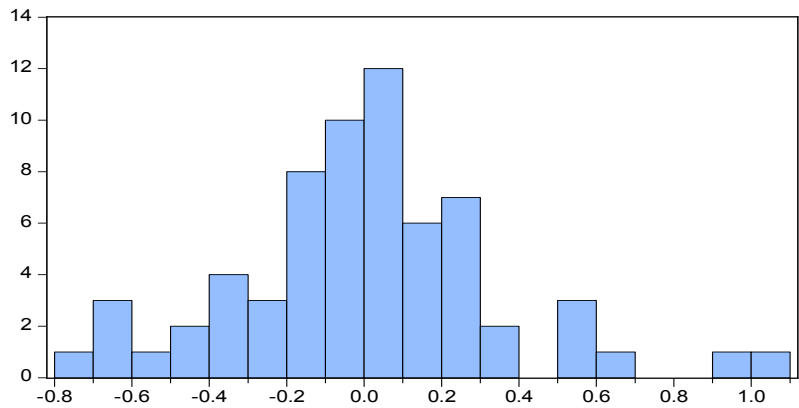

\begin{tabular}{|lr|}
\hline \multicolumn{2}{|l|}{ Series: Standardized Residuals } \\
Sample 2012 2015 \\
Observations & 65 \\
Mean & $1.69 \mathrm{e}-17$ \\
Median & 0.000000 \\
Maximum & 1.094825 \\
Minimum & -0.765627 \\
Std. Dev. & 0.347591 \\
Skewness & 0.381391 \\
Kurtosis & 4.255304 \\
& \\
Jarque-Bera & 5.843572 \\
Probability & 0.053837 \\
\hline
\end{tabular}

Figure 2. Normality Test Result

Source: Author Processed Data

sion model has a variant inequality from one observation to another or not (Ghozali, 2007). The method used in this research is using the Park Test. The criteria for this testing is if the probability value is $\geq 0.05$ then there is no problem of heteroscedasticity.

Based on Table 7, the value of all probabilities are all above 0.05 , so this research does not have a problem of heteroscedasticity.

\subsection{Hypothesis Test}

After going through the Classical Assumption Tests, the result of the Multiple Linear Regression is as follows:

Based on the result of the research regression, the obtained multiple linear regression equation is as follows in table 8 .

\section{$\mathrm{LnCH}=-4.080261-8.525178 \mathrm{IO}-2.627466 \mathrm{FO}$ \\ -0.511419 BS -0.475863 BC +1.222057 Ln- SIZE + 0.292131 GROWTH}

- Insider Ownership (IO) has a probability of $0.0955<0.10$. With a significance level of $\alpha=$ 0.10 . The results showa that Insider Ownership
(IO) has a significant influence on liquidity policy. The value of the Insider Ownership (IO) regression coefficient is -8.525 .178 , and it indicates that Insider Ownership (IO) negatively affects the dependent variable.

- Foreign Ownership (FO) has a probability of $0.5298<0.05$. With a significance level of $\alpha=$ 0.05. The results show that Foreign Ownership (FO) has no significant effect on liquidity policy. The value of Foreign Ownership (FO) regression coefficient is -2.627 .466 , indicating that Foreign Ownership (FO) has negative effect on the dependent variable.

- Board Size (BS) has a probability of $0.0492<0.05$. With a significance level $\alpha=0.05$. The results show that Board Size (BS) has a significant influence on liquidity policy. The Board Size (BS) regression coefficient value is -0.511419 , indicating that Board Size (BS) negatively affects the dependent variable.

- Board Composition (BC) has a probability of $0.1358<0.05$. With a significance level $\alpha=0.05$. The results show that Board Composition (BC)

Table 5. Multicollinearity Test Results

\begin{tabular}{cccccccc}
\hline & LnCH & IO & FO & BS & BC & LnSIZE & GROWTH \\
\hline LnCH & 1.000 & 0.240 & -0.116 & 0.199 & 0.125 & 0.674 & -0.039 \\
IO & 0.240 & 1.000 & -0.506 & -0.085 & 0.336 & 0.421 & -0.052 \\
FO & -0.116 & -0.506 & 1.000 & 0.282 & -0.242 & -0.493 & -0.095 \\
BS & 0.199 & -0.085 & 0.282 & 1.000 & -0.404 & 0.091 & -0.047 \\
BC & 0.125 & 0.336 & -0.242 & -0.404 & 1.000 & 0.257 & -0.044 \\
LnSIZE & 0.674 & 0.421 & -0.493 & 0.091 & 0.257 & 1.000 & 0.140 \\
GROWTH & -0.039 & -0.052 & -0.095 & -0.047 & -0.044 & 0.140 & 1.000 \\
\hline
\end{tabular}

Source: Author Processed Data

Table 6. Autocorrelation Test Results

\begin{tabular}{ll}
\hline Mean dependent var & 25.52994 \\
\hline S.D. dependent var & 1.616107 \\
Akaike info criterion & 1.478148 \\
Schwarz criterion & 2.314451 \\
Hannan-Quinn criter. & 1.808124 \\
Durbin-Watson stat & 1.871910 \\
\hline
\end{tabular}

Source: Author Processed Data 
Table 7. Heteroscedasticity Test Results

\begin{tabular}{ccccc}
\hline Variable & Coefficient & Std. Error & t-Statistic & Probability \\
\hline IO & -8.525 .178 & 4.993 .069 & -1.707 .402 & 0.0955 \\
FO & -2.627 .466 & 4.145 .344 & -0.633835 & 0.5298 \\
BS & -0.511419 & 0.252162 & -2.028 .134 & 0.0492 \\
BC & -0.475863 & 0.312574 & -1.522 .403 & 0.1358 \\
LnSIZE & 1.222 .057 & 0.358486 & 3.408 .941 & 0.0015 \\
GROWTH & 0.292131 & 0.254786 & 1.146 .573 & 0.2584 \\
C & -4.080 .261 & 1.037 .594 & -0.393243 & 0.6962 \\
\hline
\end{tabular}

Source: Author Processed Data

has no significant effect on liquidity policy. The value of the Board Composition (BC) regression coefficient of -0.4758639 , and it shows that Board Composition (BC) negatively affects the dependent variable.

The value of coefficient of determination (Adjusted $R^{2}$ ) is 0.925985 or $92.5985 \%$, this indicates that the independent variables of Insider Ownership (IO), Foreign Ownership (FO), Board Size (BS), Board Composition (BC) and control variables of Firm Size (LnSIZE) and Sales Growth (GROWTH) have an effect of $92.5985 \%$ to the dependent variable. The rest of $7.4015 \%$ is explained by other variables not used in this research model.

\subsection{Managerial Implications}

Based on the result of the data analysis on the influence of Ownership Structure, Corporate Governance on Liquidity Policy of Manufacturing Companies in Consumer Goods Sector in Indonesia Stock Exchange (BEI) in the period of 2012-2015, there are some things that can be considered and that can used for the company, the investor and party - interested parties to find out whether the Ownership Structure, Corporate Governance has an effect to Liquidity Policy as measured by Cash Holdings.

Insider ownership shows a negative effect. The results of this study provide an overview that most sample companies have share ownership of boards and managers but managers within the company have an opportunity to drive their own needs to the use of corporate cash so that asymmetric information occurs and they will hold more cash that causes liquidity not being able to be maintained.
It is necessary to provide the role and control in the ownership structure to its managers so that the shareholders (investors) who simultaneously serve as managers within the company are motivated to safeguard the value of the company by using excess cash on profitable projects rather than maximizing profit for their own sakes.

Foreign ownership shows no negative effect. The results of this study provide an illustration that foreign investors in Indonesia are mostly in the form of institutions and that they prefer shares of a company with high dividend rates and foreign investors in Indonesia has a high average value of $49.6 \%$. Thus, corporate managers need to be more selective when they are informing positive signals to investors as well as potential investors who want to invest in the company. This is being done so that cash management within the company remains optimal and the company is not harmed by the presence of foreign investors.

The board size shows a negative effect. This is because the company will have difficulty in performing its role to coordinate and communicate among members of the board of commissioners, so it can be said that it is not effective to face greater cost-effectiveness to hold more cash. Therefore, it is important for the company to apply good corporate governance so that cash is not being misused by management so that liquidity can be maintained.

Board composition shows no negative effect. The results of this study provide a picture that there are some companies that do not have an independent commissioner in which the company is not in accordance with applicable corporate governance rules, should have at least

Table 8. Multiple Linear Regression Data Results

\begin{tabular}{ccccc}
\hline Variable & Coefficient & Std. Error & $\boldsymbol{t}$-Statistic & Probability \\
\hline IO & -8.525 .178 & 4.993 .069 & -1.707 .402 & 0.0955 \\
FO & -2.627 .466 & 4.145 .344 & -0.633835 & 0.5298 \\
BS & -0.511419 & 0.252162 & -2.028 .134 & 0.0492 \\
BC & -0.475863 & 0.312574 & -1.522 .403 & 0.1358 \\
LnSIZE & 1.222 .057 & 0.358486 & 3.408 .941 & 0.0015 \\
GROWTH & 0.292131 & 0.254786 & 1.146 .573 & 0.2584 \\
C & -4.080 .261 & 1.037 .594 & -0.393243 & 0.6962 \\
\hline
\end{tabular}

Source: Author Processed Data 
$30 \%$ of the total members of the board of commissioners. The larger the independent board of commissioners' then the oversight of cash will be more stringent and objective and this is what causes cash ownership to be reduced. Therefore, the presence of independent commissioners within the company is important to encourage the implementation of good corporate governance principles in order to tighten cash oversight and so that the liquidity can be maintained.

The most influential variable on the research is Firm Size. Firm Size is said to have a positive effect due to the high cash flow operations. Therefore, the company needs to increase cash holdings along with the increase of its assets.

\section{Conclusion and Suggestions 5.1 Conclusions}

A. Insider Ownership of the ownership structure negatively affects Cash Holdings proxy from liquidity policy. This happens because managers have the opportunity to push their own needs in the use of corporate cash so it causes asymmetric information and they will hold more cash which then will cause liquidity unable to be maintained.

B. Foreign Ownership of the ownership structure has no negative effect on Cash Holdings proxy from liquidity policy. This is because foreign investors in Indonesia, who are mostly in the form of institutions, prefer a company with high dividend division rate and foreign investors in Indonesia has a high average value of $49.6 \%$.

C. Board Size of corporate governance negatively affects Cash Holdings proxy from liquidity policy. This is because the company will have difficulty in performing its role to coordinate and communicate among members of the board of commissioners so it can be said it is not effective to deal with a larger agency cost so as to hold more cash.

D. Board Composition of corporate governance does not negatively affect Cash Holdings proxy of liquidity policy. This is because the number of independent commissioners must be able to ensure that the monitoring mechanism is running effectively so that cash oversight will be more stringent if the number of independent commissioners increases. This causes cash holdings to decrease.

\subsection{Suggestions}

1. For Investors

High level of cash can show the ability of a company in maintaining its liquidity, so the company can be a target of investment. In addition, the level of dividend payout by the company also needs to be considered. This is related to the incentives received by investors. However, there is one more thing that really needs to be considered in choosing a company, which is corporate governance. With good corporate governance, cash holdings can be managed optimally.

\section{For the Company}

Companies need to be more selective when they are signaling positive signals to investors and potential investors who want to invest in the company. This is so that cash management within the company is maintained and the company is not harmed by the presence of inside investors and outside investors. In addition, the company also needs to adjust the number of boards of commissioners and the number of independent board of commissioners by following the applicable regulations, this is so that the complexity of the company can be maintained and the decision on cash can be more effective, accurate and independent.

\section{For Academics}

For those who want to do research in the similar field, it is expected to change the proxy of the ownership structure. Because the ownership of shares by foreigners that belong to the minority group produced insignificant influence. Therefore, for further research, it is suggested to use other proxies of ownership structure, such as institutional share ownership in order to produce a significant effect on the company's cash holdings policy.

\section{References}

Adelia, P. (2012). Pengaruh Kepemilikan Keluarga dan Kepemilikan Asing Terhadap Pengungkapan Corporate Social Responsibility. Depok: Akuntansi UI.

Bokpin, G. A., Isshaq, Z., \& Aboagye-Otchere, F. (2011). Ownership Structure, Corporate Governance, and Corporate Liquidity Policy: Evidence From The Ghana Stock Exchange. Journal of Financial Economic Policy, Volume 3, 262-279.

Brigham, E. F., \& Houston, J. F. (2001). Manajemen Keuangan II. Jakarta: Salemba Empat.

Clara, D, N. (2015). Analisis Pengaruh Struktur Kepemilikan, Board Size, Leverage Dan Growth Opportunity Terhadap Profitabilitas Perusahaan (Studi Empiris Pada Perusahaan BUMN Non Keuangan Yang Listing di Bursa Efek Indonesia Tahun 2010-2013). Semarang: Ekonomi \& Bisnis UNDIP.

Daftar Nama Perusahaan Manufaktur Sub Sektor Industri Barang Konsumsi. 28 April 2016. http:// www.sahamok.com/emiten/sektor-industri-barangkonsumsi/sub-sektor-lainnya-industri-barangkonsumsi/.

Fajar, A., \& Kusumawaru, R. (2014). Pengaruh 
Karakteristik Perusahaan dan Board Size Terhadap Corporate Cash Holdings. Depok: FISIP UI.

Fala, D., Y. (2007). "Pengaruh Konservatisme Akuntansi terhadap Penilaian Ekuitas Perusahaan Dimoderasi oleh Good Corporate Governance". Simposium Nasional Akuntansi X, IAI, 2007.

Ferreira, M., C. \& A. S. Vilela. (2004). "Why do firms hold cash? Evidence from EMU countries". European Financial Management 10(2): 295-319.

Fitri, N. (2012). Pengaruh Corporate Governance, Kepemilikan Manajerial, Dan Cash Holding Dalam Upaya Meningkatkan Kesejahteraan Pemegang Saham. Depok: Akuntansi UI.

Ginglinger, E., \& Saddour, K. (2007). Cash Holdings, Corporate Governance and Financial Constraint. Journal of Financial Economics, 68-75: 109.

Ghozali, Imam. (2007). Aplikasi Analisis Multivariate Dengan Program SPSS 21. Semarang: Universitas Diponegoro.

Ghozali, Imam. (2009). Aplikasi Analisis Multivariate Dengan Program SPSS 21. Edisi Keempat. Semarang: Universitas Diponegoro.

Ghozali, Imam. (2013). Aplikasi Analisis Multivariate Dengan Program IBM SPSS 21. Edisi Ketujuh. Semarang: Universitas Diponegoro.

Gill, A., \& Shah, C. (2012). Determinants of Corporate Cash Holdings: Evidence from Canada. International Journal of Economics and Finance, Volume 4 Number 1, 70 .

Gujarati, D. N. (2007). Dasar-Dasar Ekonometrika. Jakarta: Erlangga.

Hamidullah, S, R., \& Saeed, G. (2012). Corporate Ownership Structure \& Firm Excess Cash Holdings: Evidenced From Emerging Market Pakistan, Volume 7 (2), 228-244.

Hansen, R. S., \& Crutchley C. E. (1989). A Test of The Agency Theory of Managerial Ownership, Corporate Leverage, and Corporate Dividends. Financial Management, 18, 36-46.

Harmanto. (1987). Analisis Laporan Keuangan. Yogyakarta: BPFE.

IDX (Indonesia Stock Exchange) (2010). Bursa Efek Indonesia April 30, 2016. www.idx. co.id/id.id/beranda/perusahaantercatat/ laporankeuangandantahunan.aspx.

Ira, K. (2012). Analisis Pengaruh Board Governance Dan Cash Holding Terhadap Nilai Perusahaan (Studi Empiris Pada Perusahaan-Perusahaan Yang Terdaftar Di Bursa Efek Indonesia Periode 2005-2010). Depok: Ilmu Administrasi Negara UI.
Jensen, M. C., \& Meckling W. H. (1976). Theory of The Firm: Managerial Behavior, Agency Costs, and Ownership Structure. Journal of Financial Economics, Volume 3, 305-360.

Jensen, M. C., \& Meckling W. H. (1996). Agency cost of Free Cash Flow, Corporate Finance and Takeovers. American Economic Review 76 (2), 323-329.

Kasmir. (2010). Pengantar Manajemen Keuangan. Jakarta: Kencana Media Group.

Komite Nasional Kebijakan Governance (KNKG) (2006, Oktober 17). Pedoman Umum Good Corporate Governance Indonesia. April 27, 2016. http://www. ecgi.org/codes/documents/indonesia cg 2006 id.pdf.

Kusnadi, Y. (2003). Corporate Cash Holdings, Board Structure, and Ownership Concentratiom: Evidence from Singapore. Hongkong University of Science and Technology, 1-33.

Kusumajati, W. (2009). Analisis Pengaruh Indikator Risiko Berdasarkan Akuntansi Terhadap Risiko Sistematis Saham Sektor Industri Barang Konsumsi Periode 2003-2007. Depok: Manajemen UI.

Luo, Q., \& Hachiya, T. (2005). Corporate Governance, Cash Holdings and Firm Value: Evidence from Japan, Volume 8 Number 4.

Mangena, M. (2007). Disclosure, Corporate Governance \& Foreign Ownership On The Zibabwe Stock Exchange. 18-2.

Masdupi, E. 2005. Analisis Dampak Struktur Kepemilikan Pada Kebijakan Hutang Dalam Mengontrol Konflik Keagenan. Jurnal Ekonomi dan Bisnis Indonesia. Volume 20 Nomor 1, 57-69.

Mensah, S,M Aboagye, A.Q.Q., Addo, E, and Buatsi, S. (2003). Corporate Governnace and Corruption in Ghana: Empirical Findings and Policy Implications. African Capital Markets Forum.

Modolo, D. P. R., \& Pontes, L. T., \& ,Funchal. B. (2010). Effects of Corporate Governance Attributes On Cash Holdings For New And Old Economy Firms: The Brazilian Case. 1-14.

Myers, S. C., \& Rajan, R.G. (1998). The Paradox of Liquidity. The Quarterly Journal of Economics, 113733-771.

Nadeem, A, S., \& Khan, M, I. (2015). The Impact of Board Attributes \& Insider Ownership On Corporate Cash Holdings: Evidence From Pakistan, Volume 9(1), 52-68.

Nurmasari, N. D. (2015). Pengaruh Kepemilikan Manajerial, Kepemilikan Instutusional, Kebijakan Dividen, Pertumbuhan Perusahaan, Dan Profitabilitas Terhadap Kebijakan Hutang Perusahaan (Studi 
Empiris Pda Perusahaan Manufatur Yang Terdaftar Di Bursa Efek Indonesia). Yogyakarta: Manajemen Universitas Negeri Yogyakarta.

Papaioannou, G. J., Storck, E., \& Travlos, N.G. (1992). Ownership Structure and Corporate Liquidity Policy, Managerial and Decision Economics, Volume 13, 315-322.

Perubahan Kepemilikan Asing Terkait Peraturan ESDM No.27 Tahun 2013. Agustus 18, 2016. http://m. hukumonline.com/klinik/detail/1t527c349fo2c7a/ perubahankepemilikan-asing-terkait-peraturanesdm-no-27-tahun-2013.

Prasentianto, H. (2014). Analisis Faktor-Faktor Yang Mempengaruhi Tingkat Cash Holdings (Studi Empiris Pada Perusahaan Property Dan Real Estate Yang Terdaftar di Bursa Efek Indonesia (BEI) Tahun 2009-2010). Semarang: Ekonomika dan Bisnis Universitas Dipenogoro.

Ross, S. A., Westerfield, R, W., \& Jaffe, J. (2010). Corporate Finance (9th ed). New York: McGrawHill.

Saunders, A., \& Cornett, M. M. (2003). Financial Markets and Institutions: A Modern Perspective. New York: McGraw-Hill.

Shleifer, A., \& Vishny, R. W. (1997). A Survey of Corporate Governance. The Journal of Finance, Volume 52. 737-783.

Subramanyam, K. R., \& Wild, J. J. (2010). Analisis Laporan Keuangan. Edisi Kelima, Buku kedua, diterjemahkan oleh Yanti, D. Jakarta: Salemba Empat.

Sugiyono. (2006). Statistika Untuk Penelitian. Edisi Kesembilan. Bandung: Alfabeta.

Surya, I., \& Yustiavandana, I. (2006). Penerapan Good Corporate Governance: Mengesampingkan HakHak Istimewa Demi Kelangsungan Usaha. Jakarta: Kencana Prenada Media Group.

Wahyudi, U., dan H.P. Pawestri. (2006). Implikasi Struktur Kepemilikan Terhadap Nilai Perusahaan: dengan Keputusan Keuangan Sebagai Variabel Intervening. Simposium Nasional Akuntansi 9 Padang. K-AKPM 17.

Windy, O. (2012). Analisis Pengaruh Struktur Aset, Tingkat Pertumbuhan Pasar, Tingkat Profitabilitas, Tingkat Likuiditas Dan Non-Debt Tax Shield Terhadap Struktur Modal Perusahaam: Studi Empiris Peurusahaan Minyak Dan Gas Bumi Periode 20072010. Depok: Akuntansi 2012.

Wiyarsi, B. R. (2012). Pengaruh Corporate Governance Terhadap Manajemen Laba (Studi Empiris Pada Perusahaan Manufaktur Yang Terdaftar di Bursa Efek Indonesia (BEI) Tahun 2008-2010. Surakarta: Ekonomi Universitas Muhammadiyah Surakarta.
World Investment Report (2013). Global Value Chains: Investment and Trade For Develompent. Mei 5, 2016. http://unctad.org/en/PublicationsLibrary/wir2013 en.pdf. 